DOI: 10.15503/onis2011-22-27

\title{
Wojna SPRawiedliwa u św. Tomasza z Akwinu
}

\author{
WŁODZIMIERZ JAN ZIÓєKOWSKI \\ wlodzimierz.ziolkowski@gmail.com
}

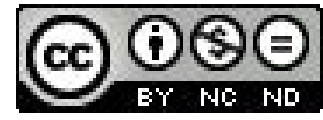

Mówiąc o koncepcji wojny sprawiedliwej u św. Tomasza z Akwinu warto zdać sobie sprawę z miejsca, jakie zajmuje w jego filozofii. Należy przede wszystkim powiedzieć, że Akwinata był jednak w pierwszej kolejności teologiem. Dlatego też, należy w jego twórczości ściśle odróżnić wątki teologiczne od filozoficznych. Ponadto zajmował się on właściwie każdą dziedziną filozofii, jaka wówczas była uprawiana. Filozofia polityczna odgrywała u niego dość istotną rolę, jednak twierdzenie, że zajmowała centralną pozycję byłoby mocną przesadą. Sama zaś koncepcja wojny sprawiedliwej w obrębie jego filozofii politycznej była raczej zagadnieniem o marginalnym znaczeniu. Poświęcił jej bowiem jedną kwestię w swojej Sumie teologii, poza tym, uwagi na temat wojny sprawiedliwej i wojny w ogóle rozsiane są w zasadzie po całej jego spuściźnie w rozmaitych kontekstach. Prześledzenie tych uwag wnosi dość dużo dla lepszego zrozumienia tej koncepcji, jednakże zasadnicze jej zręby znajdują się w kwestii 40 drugiej części drugiej części Sumy teologii.

Koncepcja wojny sprawiedliwej mieści się w szerszym kompleksie zagadnień, który określa się ogólnym mianem władzy miecza. W jego obrębie mieści się obrana przez samego siebie i innych, kara główna, wojna sprawiedliwa i zabójstwo tyrana. Żadne jednak z tych zagadnień (oczywiście poza samą wojną sprawiedliwą) nie jest niezbędne dla zrozumienia koncepcji wojny sprawiedliwej, dlatego w artykule tym zostaną pominięte. Trzeba tu jednak wspomnieć o kilku sprawach, które w jakiś sposób pojawiają się przy okazji omawiania wszystkich elementów tego kompleksu. Przede wszystkim trzeba zwrócić uwagę na to, że św. Tomasz rozróżnia między czysto technicznym terminem occisio (który odnosi się do każdego sposobu pozbawienia kogoś życia) a homicidium. Termin occisio nie posiada kwalifikacji moralnej i jest pojęciem ogólnym obejmującym zarówno pozbawienie kogoś życia przez Boga, jak i akt dokonywany przez najbardziej bezwzględnego mordercę. Czym innym jest natomiast homicidium, czyli morderstwo. Jest to akt dokonywany przez człowieka na podstawie świadomej i zarazem niesprawiedliwej decyzji o pozbawieniu kogoś życia. Decyzja ta nie posiada żadnego innego usprawiedliwienia, niż wola podmiotu działającego i jako taka jest moralnie zła. Żaden człowiek nie ma bowiem prawa zabić innego tylko na podstawie swojej własnej woli. Drugą sprawą jest coś, co można określić mianem koncepcji intencji. Otóż człowiek może w swym akcie zamierzyć pewną rzecz (np. podczas walki ochronę własnego życia) oraz dopasować proporcjonalnie do tego zamierzenia środki (wykluczając rozmyślne uśmiercenie kogoś), a mimo to spowodować śmierć swego przeciwnika. W takim wypadku śmierć ta jest skutkiem ubocznym prawej decyzji i w najmniejszym stopniu nie obciąża sumienia sprawcy. Te dwie sprawy warto mieć na uwadze przy omawianiu wojny sprawiedliwej, ponieważ ich znaczenie jest tu niebagatelne, wnoszą bardzo dużo do zrozumienia tego zagadnienia (choć może nie bezpośrednio).

Podstawę teoretyczną dla uzasadnienia możliwości prowadzenia wojny Akwinata pokazuje na kilka sposobów. Podstawowym argumentem jest to, że właściwym przedmiotem cnoty męstwa jest znoszenie niebezpieczeństw, z jakimi ma człowiek do czynienia podczas wojny.

1 Dla przypomnienia warto wspomnieć, że Suma teologii jest podzielona na cztery główne części: pierwszą pierwszą drugiej, drugą drugiej i trzecią. 
Męstwo bowiem polega nade wszystko na tym, że człowiek nie uchyla się od niebezpieczeństw z tego tylko powodu, że są niebezpieczeństwami. I o ile człowiek nie przeraża się niebezpieczeństw, które towarzyszą różnym groźnym zdarzeniom, które niekoniecznie towarzyszą jakiemuś dobru, o tyle nie ulęknie się niebezpieczeństw, które towarzyszą jakiemuś dobru. A obrona dobra publicznego podczas wojny sprawiedliwej jest jednym z najwyższych dóbr, do których osiagnięcia może dążyć człowiek. Dlatego też wojna i to nie tylko rozumiana ogólnie, ale także w każdej najmniejszej potyczce, jest w najwłaściwszym sensie sytuacja, w której może się ujawniać męstwo, a tym samym jest nie tylko dozwolona, ale jest też okazją do wykazana się cnotą ${ }^{2}$. Ponadto walka z nieprzyjaciółmi jest wskazana dlatego, że jest sposobem powstrzymywania ich od popełnienia grzechu, co wychodzi na dobre zarówno im samym, jak i ich bliźnim. Że zaś wolno ich od grzechu powstrzymywać pokazuje analogia z modlitwa, podczas której prosi się niekiedy Boga, aby powstrzymał bliźnich od popełnienia grzechu. Kiedy zaś walczy się z nieprzyjaciółmi czyni się to, co jest zgodne z intencjami modlitw za bliźnich³.

Najistotniejsza dla koncepcji wojny sprawiedliwej św. Tomasza z Akwinu jest kwestia czterdziesta drugiej części drugiej części jego Sumy teologii. Wyjaśnia on w niej podstawowe zagadnienia dotyczące wojny, w tym w szczególności wojny sprawiedliwej. Przede wszystkim wskazuje w niej na to, że nie można z chrześcijańskiego punktu widzenia zaprzeczyć temu, iż wojna może być usprawiedliwiona oraz nikt nie może chrześcijan odwodzić od udziału w wojnach. Powołuje się na św. Augustyna, który w kazaniu o synu setnika mówi, że Chrystus nigdy nie nakazał żołnierzom występować z armii, lecz jedynie zakazał im mordować oraz nakazał poprzestać na żołdzie, czyli nie grabićt. Należy to swoją drogą rozumieć tak, że zabicie kogoś na wojnie przez żołnierza jest czymś zupełnie innym niż morderstwo ${ }^{5}$. Jednakże wojna - aby była wojną sprawiedliwą - winna spełniać kilka warunków.

Przede wszystkim niezbędnym jej warunkiem jest władza księcia (auctoritas principis). Tylko z rozkazu władzy publicznej, określanej przez Akwinatę terminem princeps, wolno prowadzić wojnę. Osoba prywatna nie może prowadzić przeciw komukolwiek wojny, gdyż może swych praw dochodzić przed sądem. Podobnie też powołanie ludzi (poddanych) pod broń - co jest niezbędne podczas wojny - nie należy do osoby prywatnej, lecz do władzy publicznej, gdyż to ona ma się zajmować obroną kraju, który jest jej powierzony. A ponieważ może ona karać mieczem wewnętrznych wrogów pokoju ${ }^{6}$, to także i zewnętrznych agresorów może 7 .

Kolejnym warunkiem wojny sprawiedliwej jest sprawiedliwa przyczyna (iusta causa). Oczywiście naturalne jest, że państwo zaatakowane przez inne państwo ma prawo się bronić, wynika to $\mathrm{z}$ naturalnego prawa do samoobrony ${ }^{8}$ (choć ograniczać się wyłącznie do samoobrony w wielu wypadkach nie wolno, lecz trzeba podejmować działania ofensywne'). Ponadto każdy, kto jest zwalczany, na zwalczanie zasłużył jakaśs winą. Według św. Augustyna, którego Tomasz przytacza, wojna sprawiedliwa musi mścić jaką́s krzywdę. Dzieje się to w sytuacji, gdy jakiś kraj trzeba ukarać, gdy tenże kraj zaniedbał sam ukarać to, co jego mieszkańcy uczynili źle lub oddać to, co

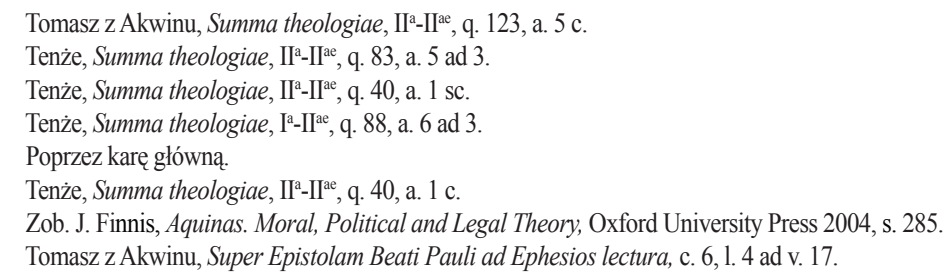


zostało zabrane w zbrodniczy sposób ${ }^{10}$. Specyficznym rodzajem sprawiedliwej przyczyny wojny jest wojna prowadzona przeciwko poganom. O ile bowiem zdaniem św. Tomasza nie wolno prowadzić wojny przeciwko jakimkolwiek poganom by ich przymusić do wiary w Chrystusa, o tyle walczyć z nimi, by nie prześladowali tejże wiary i nie utrudniali chrześcijanom jej praktykowania, z całą pewnością nie tylko wolno, ale wręcz trzeba. Dlatego też, tego rodzaju wojny toczone przez chrześcijańskich władców są uzasadnione i dopuszczalne. Co innego jednak w wypadku heretyków i innych odstępców. Ci ludzie, którzy kiedyś wyznawali prawdziwą wiarę i od niej odpadli mogą i powinni-zdaniem św. Tomasza - być zmuszeni do powrotu do niej ${ }^{11}$. Uzasadnia to przez przykład - podobieństwo do przysięgi. Nikt przysięgać nie musi, bo jest to rzeczą woli, gdy jednak już raz przysięgnie, do dotrzymania obietnicy niekiedy trzeba go zmusić1 ${ }^{2}$.

Trzecim warunkiem, który się pojawia jest uczciwa intencja (intentio recta) wojujących. Musi ona zakładać bądź powiększenie dobra bądź unikanie zła. Św. Tomasz po raz kolejny powołuje się na Augustyna, który powiedział, że u prawdziwych czcicieli Boga nawet wojny są pokojowe bo nie są one prowadzone z żądzy lub okrucieństwa lecz dla pokoju oraz po to, żeby złych powściągać a dobrych popierać. Gdyby zaś zdarzyła się sytuacja, że przy prawowitej władzy i sprawiedliwej przyczynie intencja byłaby nieuczciwa, wojna stałaby się niesprawiedliwa ${ }^{13}$. Dotyczy to na przykład sytuacji, $w$ której uczestnicy wojny zaczęliby się oddawać zdobywaniu dóbr materialnych i przedkładać to nad wszystkie inne cele wojny. Byłby to pospolity rabunek i przez to wojna byłaby niesprawiedliwa. Czym jednak innym jest podejmowanie wojny dla rabunku, co świadczy o odejściu od właściwej intencji wszczęcia wojny, a czym innym jest wchodzenie przemocą $\mathrm{w}$ trakcie działań wojennych $\mathrm{w}$ posiadanie jakichś dóbr materialnych. Otóż to ostatnie $-\mathrm{z}$ umiarem naturalnie realizowane - jest jak najbardziej dopuszczalne ${ }^{14}$. Co ciekawe, dopuszczalne zdaniem Akwinaty jest także, żeby w trakcie wojny sprawiedliwej wejść w posiadanie niewolników. Gdyby jednak dokonało się to podczas wojny niesprawiedliwej byłoby niedopuszczalne i z moralnego punktu widzenia właściciel niewolników tak nabytych musiałby zwrócić im wolność ${ }^{15}$. Ponadto trzeba wojnę rozpoczynać sprawiedliwie, kiedy się więc jąjakiemuś państwu wypowiada, należy mu najpierw zaoferować pokój. Wojnę już podjętą trzeba mężnie doprowadzić do skutku, korzystając z danej przez Boga odwagi. Ponadto należy usuwać przeszkody do walki, co polega np. na odsyłaniu do domu tych, którzy mogliby się w walce okazać przeszkodą chociażby poprzez swój strach. Kiedy już zaś się wojnę wygra, ze zwycięstwa należy korzystać w sposób umiarkowany. Nie wolno praktykować polityki „żadnych jeńców”, co więcej należy bezwzględnie oszczędzać kobiety i dzieci, a także nie wolno niszczyć drzew owocowych w danym regionie (co zapewne należy rozumiećjako zakaz niszczenia wszelkich upraw) ${ }^{16}$.

Prócz określenia warunków wojny sprawiedliwej św. Tomasz rozstrzyga kilka kwestii szczegółowych, które ściśle się z tym zagadnieniem wiąża, choć nie mają już wpływu na to, czy dana wojna będzie sprawiedliwa.

Przede wszystkim należy wspomnieć o rozważaniach dotyczących osób uczestniczących w wojnie. Nie każdy bowiem może w wojnie uczestniczyć. Najważniejszą kategorią osób, która jest wykluczona od udziału w wojnie, a o której pisze św. Tomasz, są duchowni. Nie mogą oni

\footnotetext{
10 Tenże, Summa theologiae, II $^{\text {a }}{ }^{\text {ae }}{ }^{\text {, }}$, q. 40, a. 1 c.

11 Tenże, Summa theologiae, II ${ }^{\mathrm{a}}-\mathrm{II}^{\mathrm{ae}}$, q. 10, a. 8 c.

12 Tenże, Summa theologiae, II $^{\mathrm{a}}-\mathrm{II}^{\text {ae }}$, q. 10 , a. 8 ad 3.

13 Tamże.

14 Tenże, Summa theologiae, II $^{\mathrm{a}}-\mathrm{II}^{\mathrm{ae}}$, q. 66, a. 8 ad 1 .

Tenże, Sententia libri Politicorum, lib. I, 1. 5, n. 7.

Tenże, Summa theologiae, I ${ }^{\mathrm{a}}-\mathrm{II}^{\mathrm{ae}}$, q. 105, a. 3 c.
} 
uczestniczyć $\mathrm{w}$ wojnie $\mathrm{z}$ dwóch racji. Po pierwsze dlatego, że ich powołanie jest wyższe od powołania żołnierza i choć służba żołnierska jest zaszczytna i wolno ją pełnić, to jednak niesie ze sobą wiele pokus i mogłaby odciągać duchownych od kontemplacji spraw boskich, która to kontemplacja jest ich podstawowym zadaniem. Po drugie nie przystoi im zabijać i doprowadzać do rozlewu krwi, gdyż ich zadaniem jest służba ołtarza, podczas której pod znakiem sakramentalnym uobecnia się męka Chrystusa. $Z$ tego też powodu nie przystoi im zabijać lecz raczej życiem naśladować to, co czynią w misterium, co zaś polega na gotowości wylania swej własnej krwi by tym doskonalej naśladować $\mathrm{Chrystusa}^{17}$. Mimo jednak iż duchowni są powołani do rzeczy większych $^{18}$, to mogą a nawet powinni w wojnie brać udział, nie po to jednak, by brać udział w walkach, lecz aby udzielać duchowego wsparcia żołnierzom we wszystkich sytuacjach, jakie tych ostatnich spotykają podczas działań wojennych ${ }^{19}$. Warto tu jeszcze wspomnieć o pewnej kwestii, która na pozór stoi w sprzeczności z tym, co dotychczas zostało powiedziane o udziale w wojnie duchownych. Otóż na pytanie o to, czy może powstać zakon powołany do prowadzenia działań wojennych (walki), św. Tomasz odpowiada, że jak najbardziej może. Zakon taki zaliczałby się nie do zakonów powołanych do życia kontemplacyjnego lecz do życia czynnego. Zakon powołany do życia czynnego ma za zadanie służyć bliźnim, a jego celem jest posłuszeństwo Bogu. Nie może zaś charakteryzować się przywiązaniem do rzeczy światowych. Co więcej służba wojskowa może polegać nie tylko na pomocy indywidualnym bliźnim lecz także na obronie państwa, lub też na obronie bożego kultu. Dlatego zakon może być ustanowiony dla ochrony Bożego kultu, obrony państwa oraz biednych i uciskanych ${ }^{20}$. Zasadą pozwalającą na dopuszczenie istnienia zakonów rycerskich jest to, że człowiek wprawdzie winien wybaczać wszelkie szkody wyrządzone samemu sobie, ale nie wolno mu przebaczać, gdyby taka szkoda dotknęła innych, musi wtedy działać i dążyć do naprawienia tej szkody ${ }^{21}$. Walka zaś nie może się odbywać na podstawie władzy zakonnej, lecz kościelnej lub też władzy księcia ${ }^{22}$. Warto się jednak zastanowić nad tym, jak pogodzić istnienie zakonów rycerskich z zakazem udziału duchownych w wojnie. Do zakonu w Kościele katolickim można należeć na kilka różnych sposobów. Można być księdzem, czyli osobą duchowną mającą prawo do sprawowania wszystkich sakramentów. Można być też bratem zakonnym, który składa wprawdzie śluby ubóstwa i posłuszeństwa ale nie otrzymuje święceń kapłańskich i pozostaje de iure osobą świecka, przez co też nie może sprawować sakramentów, a w szczególności mszy św. Jest też jeszcze kilka innych sposobów przynależności do zakonu, jednak nie miejsce tu na ich opisywanie. Zakony rycerskie - jak się zdaje - posiadały przede wszystkim właśnie te dwie kategorie członkowstwa. I o ile ojcowie (księża) pełnili w nich posługę sakramentalna, o tyle bracia zakonni uczestniczyli w walkach. W ten sposób zakon mógł posiadać charakter rycerski a zarazem nie naruszać podstawowej dyrektywy w myśl której duchownym nie wolno bezpośrednio uczestniczyć w działaniach wojennych.

Kolejną kwestią jaką porusza doktor anielski jest sprawa zasadzek i podstępów (insidiae). Zasadzki i podstępy mogą być brane za zdradę. Dzieje się tak jednak niesłusznie. Wróg bowiem może zostać pokonany na dwa sposoby. Po pierwsze przez jakiś czyn lub słowo, po drugie zaś przez kłamstwo lub złamanie przysięgi. Drugi sposób jest niedozwolony (niezależnie od towa-

\footnotetext{
17 Tenże, Summa theologiae, II ${ }^{\mathrm{a}}-\mathrm{II}^{\mathrm{ae}}$, q. 40, a. 2 c.

8 Tenże, Summa theologiae, II $^{\mathrm{a}}-\mathrm{II}^{\mathrm{ae}}$, q. 40, a. 2 ad 4.

Tenże, Summa theologiae, II ${ }^{\mathrm{a}}-\mathrm{II}^{\mathrm{ae}}$, q. 40, a. 2 ad 2

Tenże, Summa theologiae, II ${ }^{\mathrm{a}}-\mathrm{II}^{\mathrm{ae}}$, q. 188, a. 3 c.

Tenże, Summa theologiae, II ${ }^{\mathrm{a}}-\mathrm{II}^{\mathrm{ae}}$, q. 188, a. 3 ad 1.

Tenże, Summa theologiae, II ${ }^{\mathrm{a}}-I^{\text {ae }}$, q. 188, a. 3 ad 4
} 
rzyszących okoliczności), gdyż jest złem moralnym; także bowiem między wrogami obowiązują prawa wojenne i przymierza ${ }^{23}$. Wolno jednak roztropnie nie ujawniać wszystkiego swemu wrogowi i w ten sposób szykować mu zgubęe ${ }^{24}$. Nikt też, kto ma uporządkowaną wolę nie może chcieć, żeby wszystko mu ujawniano. Jest tak tym bardziej, że także w wierze są takie sprawy, o których nie każdemu należy mówić (nie należy miotać pereł przed wieprze), więc tym bardziej obowiązuje to w mniej znaczącej sprawie, jaką jest wojna. W stosowaniu zasadzek, pułapek i podstępów nie ma nic przeciwnego sprawiedliwości. Ukrywanie zaś pewnych spraw jest po prostu naturalną częścią tak życia w ogóle, jak i wojny sprawiedliwej w szczególności²5.

Akwinata zajmuje się też jeszcze sprawą prowadzenia działań wojennych w dni świąteczne. Zachowanie spoczynku świątecznego nie zwalnia lekarzy z konieczności dbania o zdrowie ludzi a już zwłaszcza o jego ratowanie. Tym bardziej więc należy bronić zagrożonego zdrowia państwa (rei publice), gdyż od niego zależy zdrowie i los wielu ludzi - o tyle jest to nawet ważniejsze niż działanie lekarza. Kuszeniem Boga - jak mówi św. Tomasz - byłoby wstrzymywanie się wówczas od działania. Jednakże takie działanie jest usprawiedliwione tylko i wyłącznie w obliczu bezpośredniego zagrożenia napaścia, po ustąpieniu zaś takiego zagrożenia należy od dalszych działań się powstrzymać (o tyle też prowadzenie wojny ofensywnej w święto jest niedozwolone $)^{26}$.

$\mathrm{Na}$ koniec warto zwrócić uwagę na rzecz ciekawa, a z punktu widzenia światopoglądu wyznawanego przez św. Tomasza posiadającą wielkie znacznie. Otóż kiedy mówi o tym, jak można przestrzegać przykazania miłości Boga, że mianowicie są dwa sposoby - doskonały, dostępny dopiero w niebie i niedoskonały, który można osiaggną́ jeszcze na ziemi, przytacza jako przykład postacie dwóch żołnierzy, z których jeden wypełnia rozkaz wodza w sposób doskonały i wroga pokonuje, a drugi wypełnia ten sam rozkaz w sposób niedoskonały, bo wprawdzie wroga nie pokonuje, ale też nie popełnia żadnego wykroczenia przeciwko sztuce wojskowej i nie ucieka, lecz stara się walczyć ze wszystkich si $^{27}$. Gdyby Akwinata sądził, że w prowadzeniu wojny jest coś niestosownego, coś co by nie licowało z powagą tak wielkiego przykazania, nigdy by nie przytoczył takiego przykładu w tym kontekście.

Koncepcja wojny sprawiedliwej nie jest po prostu próbą usprawiedliwienia prowadzenia wojen. Wydaje się, że jej opracowanie wypływa z głębszej konstatacji - że wojna jest wynikiem niedoskonałości ludzkiej kondycji i jako taka będzie ludziom towarzyszyła zawsze, podobnie jak powodzie czy trzęsienia ziemi. Koncepcja ta jest próbą utemperowania obyczajów, które panowały w średniowieczu. Ponadto rozważając którąkolwiek z obecnie toczonych wojen łatwo zauważyć, że częstokroć nie spełniają one co najmniej jednego z warunków wojny sprawiedliwej. Tym samym okazuje się, że koncepcja omówiona w tym artykule doskonale nadaje się do opisu zjawisk współczesnych (mimo iż powstała przeszło siedem wieków temu), a zarazem nieźle sprawdzałaby się w roli regulatora stosunków między państwami.

23 Tenże, Summa theologiae, II ${ }^{\mathrm{a}}-\mathrm{II}^{\mathrm{ae}}$, q. 71, a. 3 ad 3.

24 Tenże, Summa theologiae, II $^{\mathrm{a}}-\mathrm{II}^{\mathrm{ae}}$, q. 110, a. 3 ad 4.

25 Tenże, Summa theologiae, II ${ }^{\mathrm{a}}-\mathrm{II}^{\mathrm{ae}}$, q. 40, a. 3 c.

Tenże, Summa theologiae, II $^{\mathrm{a}}-\mathrm{II}^{\text {ae }}$, q. 40, a. 4 c.

Tenże, Summa theologiae, II $^{\mathrm{a}}-I^{\mathrm{ae}}$, q. 44, a. 6 c. 


\section{Bibliografia}

\section{Literatura podmiotu}

Tomasz z Akwinu, Summa theologiae, www.corpusthomisticum.org.

Tomasz z Akwinu, Sententia libri Politicorum, www.corpusthomisticum.org.

Tomasz z Akwinu, Super Epistolam Beati Pauli ad Ephesios lectura,

www.corpusthomisticum.org.

\section{Literatura przedmiotu}

Finnis J., Aquinas. Moral, Political and Legal Theory, "Oxford University Press" 2004.

\section{Słowa kluczowe}

Władza miecza, obrona siebie i innych, kara główna, wojna sprawiedliwa, zabójstwo tyrana, sprawiedliwa przyczyna, władza publiczna, uczciwa intencja.

\section{STRESZCZenie}

W artykule niniejszym po omówieniu teoretycznego uzasadnienia dla prowadzenia wojny, przedstawiona została koncepcja wojny sprawiedliwej u św. Tomasza z Akwinu. Składają się na nią trzy warunki wojny sprawiedliwej: musi zostać wypowiedziana przez prawowitą władzę publiczna, przyczyna wojny musi być sprawiedliwa, a prowadzeniu wojny musi towarzyszyć uczciwa intencja. Następnie przedstawione zostały kwestie ściśle z koncepcją wojny sprawiedliwej związane. Chodzi mianowicie o osoby uczestniczące w wojnie (nie mogą to być księża), o stosowanie zasadzek i podstępów oraz o prowadzenie działań wojennych w dni świąteczne. W podsumowaniu podjęto $\mathrm{w}$ kilku zdaniach próbę ukazania aktualności tej koncepcji.

\section{Just WAR AT Thomas AQuinas}

\section{Keywords}

Power of sword, self-defence, defence, capital punishment, just war, murder of tyrant, just cause, public authority,

\section{Summary}

The article contains theoretical reasons for waging just war. Also the concept of the just war by Thomas Aquinas is presented. Three conditions must be fulfilled for a war to be just: the war must be started by legal public authority, the war must be for good, or against evil. Than different issues connected with just war will be presented, like: who is not allowed to take part in war (priests). In the summary the author of the article shows topicality of the concept of a Just War. 